\title{
Agriculture Study on Sugar Beet in Egypt
}

\section{Hager El-Zayat*}

Senior Agronomist, FarmTopia Agritech Company, Egypt

*Corresponding Author: Hager El-Zayat, Senior Agronomist, FarmTopia Agritech

Company, Egypt.
Received: August 27, 2021

Published: December 27, 2021

(C) All rights are reserved by FarmTopia.

\begin{abstract}
Sugar beet cultivation in Egypt is vital for the sugar industry's main goal since its natural properties of salinity tolerance and ability to thrive in a desert climate make it the second choice for sugar production. Traditional agriculture practices have a high level of output; however, sugar beet is one of the crops that depend on yield quality rather than quantity. For sugar producers, the amount of sugar in the tuber of the sugar beet is the most essential attribute, and it is the key predictor of yield cost. Precision agriculture approaches in sugar beet production include (sowing, irrigation, fertilization, harvest, and post-harvest) and, according to some researchers, have a positive impact on cost, time, and quality. As a result, this review contains some recommendations for excellent agricultural practices based on various scientific findings as well as environmental factors in Egypt that influence crop quality and quantity.
\end{abstract}

Keywords: Precision Agriculture; Sugar Beet; Irrigation; Fertilization; Pest Management

\section{Introduction}

\section{General}

Sugar beet is a plant its roots have a high concentration of sucrose and it used commercially for sugar production. It is known as the Altissima cultivar group of the common beet (Beta vulgaris) in plant breeding. Sugar beet cultivation has spread in Egypt in Lower and Upper Egypt governorates, and since the energy for existing crops needs to grow about 200,000 feddans in order to operate at full capacity in the El Sheikh, El Dakahlia and El Fayoum and factories, more than half a million tons of sugar. The root in sugar beet contains, on average, $75 \%$ water, $20 \%$ soluble solids, about $16 \%$ sucrose, $4 \%$ non-sugar substances, which are nitrogenous substances and mineral salts, their excess hinders the crystallization of sugar, leading to a decrease in the quality of the crop, especially sodium and potassium salts. $5 \%$ fiber, which is used in the production of fodder.

The ideal choice is cultivation Beets in August, when the plant is exposed to a relatively high temperature and grows vegetative

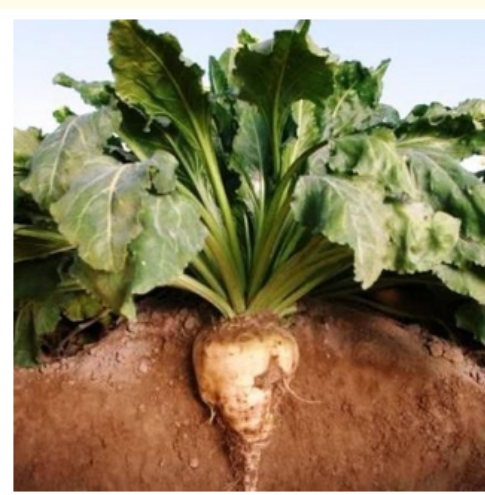

Figure 1

to be a root of a suitable size until the month of October, when the temperature begins to decrease the sucrose storage begins and the harvest begins in March.

In Egypt, the sugar beet applied in its soil for average productivity approximately 30 ton/fed [1]. In Egypt 11 million tons of sugar beets have been produced in 2018 . 


\section{Project brief}

There are several types of cultivars that are produced in Egypt.

\begin{tabular}{|l|c|c|c|}
\hline Cultivar & Origin & Cultivar & Origin \\
\hline Gloria & Germany & Pleno & Netherland \\
\hline Toro & Germany & Farida & Netherland \\
\hline Top & Germany & Demo poly & France \\
\hline Monte Bianco & Germany & Deberya poly N & France \\
\hline Kawemira & Germany & Ras poly & Sweden \\
\hline lola & Germany & H poly & Sweden \\
\hline Oscar poly & Denmark & Nejma & Sweden \\
\hline Athos poly & Netherland & Beta poly teri & Hungery \\
\hline
\end{tabular}

Table 1

The sugar beet crop needs about $1800-2500 \mathrm{~m}^{3}$ of water throughout the life of the plant, distributed over about 7-8 irrigations, which increase in light sandy lands, which may reach 15-20 irrigations. In traditional agriculture, when preparing the land for cultivation, the canal and the pit must be established, provided that the line length does not exceed 7-8 $\mathrm{m}$.

Growth Stages of sugar beet

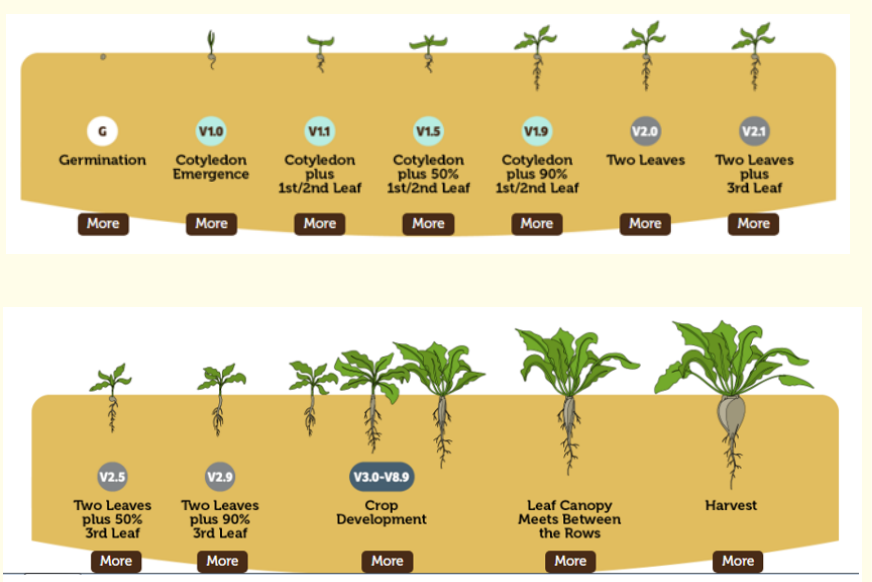

Figure 2: Common creative license.

\section{Opportunity rationale}

As Egypt is one of the countries that exports molasses that is produced from sugar beet, also the number of sugar factories in
Egypt increased, hence increasing the chance of sugar beet cultivation in Egypt as the consumption rate increase inside and outside Egypt.

\section{Environmental growth}

Temperature: The optimum temperature for plant and growth 20-30 degree Celsius.

- A daily minimum temperature above $3^{\circ} \mathrm{C}$.

- A daily maximum temperature below $30^{\circ} \mathrm{C}$ (sugar beet).

- An optimum accumulated temperature requirement of $1253^{\circ} \mathrm{Cd}$ (sugar beet) [2].

Sowing date: Early planting during August and mid-September, early germination, with a period ranging between 8-12 days.

Depth of cultivation: One of the main factors in the speed of germination is that the depth of seeds does not exceed 1-2 cm, especially in heavy lands, but in light lands, the depth of cultivation should not exceed $3 \mathrm{~cm}$, as increasing the depth of seeds leads to a delay in germination for a period that may reach more than 40 days.

Soil quality: The germination of seeds in sandy and light lands is faster than in heavy lands.

\begin{tabular}{|c|c|c|c|}
\hline Kind of soil & Parameter & Range & Reference \\
\hline $\begin{array}{l}\text { Heavy Clay } \\
\text { soil }\end{array}$ & Salinity (EC) & $\begin{array}{l}3.23 \text { and } 3.16 \mathrm{dsm}^{-1} \\
\text { before planting and } \\
\text { after harvesting }\end{array}$ & [3] \\
\hline \multirow{2}{*}{$\begin{array}{l}\text { Sandy } \\
\text { Loamy }\end{array}$} & Salinity (EC) & $0.58 \mathrm{dsm}^{-1}$ & \multirow[t]{2}{*}{ [4] } \\
\hline & $\mathrm{PH}$ & 8.1 & \\
\hline \multirow{2}{*}{$\begin{array}{l}\text { calcareous } \\
\text { soil }\end{array}$} & Salinity (EC) & $1.15-1.2$ & \multirow[t]{2}{*}[5]{} \\
\hline & $\mathrm{PH}$ & $8.4-8.5$ & \\
\hline \multirow{2}{*}{ Sandy soil } & Salinity (EC) & $1.99-2.06$ & \multirow[t]{2}{*}{ [16] } \\
\hline & $\mathrm{PH}$ & $8.13-8.15$ & \\
\hline \multirow{2}{*}{$\begin{array}{l}\text { Sandy loam } \\
\text { soil }\end{array}$} & Salinity (EC) & $\begin{array}{c}3.06 \text { and } 2.77 \\
\text { mmhos/cm }\end{array}$ & \multirow[t]{2}{*}{ [17] } \\
\hline & $\mathrm{PH}$ & $8.1-8.3$ & \\
\hline \multirow{2}{*}{ Sandy soil } & Salinity (EC) & $1.45 \mathrm{dSm}^{-1}$ & \multirow[t]{2}{*}{ [i8] } \\
\hline & $\mathrm{PH}$ & $7.9-8.1$ & \\
\hline \multirow{2}{*}{$\begin{array}{l}\text { Sandy non } \\
\text { calcareous } \\
\text { soil }\end{array}$} & Salinity (EC) & $4.6-5.21 \mathrm{dSm}^{-1}$ & \multirow[t]{2}{*}{ [9] } \\
\hline & $\mathrm{PH}$ & $7.9-8.1$ & \\
\hline
\end{tabular}

Table 2 
Soil Nutrients uptakes by sugar beet crop to produce large yield.

\begin{tabular}{|l|c|c|c|}
\hline Nutrients & Amount & Notes & Reference \\
\hline Nitrogen & $200 \mathrm{~kg} \mathrm{~N} \mathrm{ha}^{-1}$ & $\begin{array}{c}\text { More than } 50 \% \\
\text { naturally from soil } \\
\text { and the remaining } \\
\text { from fertilizers its } \\
\text { application between } \\
\text { 4-6 weeks after } \\
\text { sowing }\end{array}$ & {$[10]$} \\
\hline Potassium & $114 \mathrm{~kg} \mathrm{ha}^{-1}$ & \multicolumn{2}{|c|}{} \\
\hline
\end{tabular}

Table 3

Irrigation of agriculture: When the irrigation water is increased and the land is immersed in water for a long period without being drained, it leads to delaying germination.

\begin{tabular}{|l|c|c|}
\hline Parameter & Range & Reference \\
\hline Salinity (EC) & $1.81 \mathrm{dsm}^{-1}$ & {$[3]$} \\
\hline PH & 7.14 & \\
\hline
\end{tabular}

Table 4

The Efficiency of water irrigation in desert from $6180-6463$ $\mathrm{m}^{3} /$ ha in drip irrigation method.

According to FAO recommendation to use drip irrigation in beetroot crop [3].

Irrigation water equations:

$\mathrm{dn}=(\theta \mathrm{fc}-\theta \mathrm{w}) \mathrm{AsR}$

$\operatorname{dir}=\frac{\mathrm{dn}}{n}(\mathrm{n}+1)$

$\mathrm{V}=\left(\frac{\operatorname{dir}}{E a}\right)() \mathrm{A}$

$\mathrm{dn}$ is the net water required to provide the soil water deficit to reach field capacity within the root zone $(\mathrm{mm})$.

Өfc and $\Theta w$ are the soil water contents at field capacity and at measuring time, respectively (\%).

As is the bulk density $\left(\mathrm{g} \mathrm{cm}^{-3}\right)$

$\mathrm{R}$ is the root depth (mm)

dir is the net water requirement one day after soil water measurement or at the irrigation time ( $\mathrm{mm})$. $\mathrm{n}$ is the number of days between the last irrigation date and the soil water measuring date (which was one day before the next irrigation date).

$\mathrm{V}$ is the volume of irrigation water (liters).

Ea is the application efficiency (for subsurface drip, surface drip and furrow irrigation this was assumed to be $95 \%, 90 \%$ and $80 \%$, respectively).

A is the area of each plot $\left(\mathrm{m}^{2}\right)[12]$.

The crop evapotranspiration values were calculated according to the following equation:

$\mathrm{ETc}=\mathrm{ETo} * \mathrm{Kc}$

$\mathrm{ETc}=$ Crop evapotranspiration $(\mathrm{mm} /$ day $)$

ETo $=$ Reference evapotranspiration $(\mathrm{mm} /$ day $)$

$\mathrm{Kc}=$ Crop coefficient values for sugar beet crop

Equation of Applied Irrigation Water: $\mathrm{AIW}=\frac{\mathrm{ETc} * \mathrm{Kr} * \mathrm{I}}{\mathrm{Ea}(1-\mathrm{LR})}$

AIW: Head of applied irrigation water (mm).

ETc: Crop evapotranspiration (mm/day)

Kr: Evaporation reduction coefficient, that depends on ground cover.

I: Irrigation intervals (day),

Ea: Irrigation efficiency of the drip irrigation system

LR: Leaching requirements.

Insect infestation: In many cases, germination is greatly affected by insect infestation, especially the borer, cutworm and cotton leaf worm, which may eliminate seedlings in their buds, especially in the early lugs.

The land is prepared to be plowed at least twice in a homogeneous manner when the field moisture content is $50 \%$ (cultivated land) plowing is followed by smoothing and leveling the soil, then dividing the land into lines and basins to facilitate irrigation.

\section{Fertilization}

- It is recommended to add 60 - $80 \mathrm{~kg}$ of nitrogen per acre

- It must be added at an early age in the life of the plant so that nitrogen fertilizer is not added when the plants reach the age 
of 90 days, and nitrogen fertilizer is added in two approximately equal batches. The first batch is added immediately after thinning, and the second batch is added to the irrigation following it.

- Organic fertilizers can be added to sandy and reclaimed lands, and phosphate fertilizers are added at a rate of $100-200 \mathrm{~kg}$, superphosphate $15 \%$, and the best date for adding it is during the preparation period of the land during the plowing process so that the phosphate fertilizer can be mixed well.

Operational plan
Pests and diseases

\begin{tabular}{|l|c|}
\hline Pests & Diseases \\
\hline Mole cricket & Cercospora leaf spot (fungal disease) \\
\hline Cutworm & Powdery mildew (fungal disease) \\
\hline $\begin{array}{l}\text { Egyptian cotton leaf } \\
\text { worm }\end{array}$ & Damping off (fungal disease) \\
\hline Flea beetle & Nematodes \\
\hline Mangold fly & $\begin{array}{c}\text { Hollow Heart (Nitrogen fertilization } \\
\text { increase) }\end{array}$ \\
\hline & Black heart (deficiency of boron) \\
\hline
\end{tabular}

Table 5

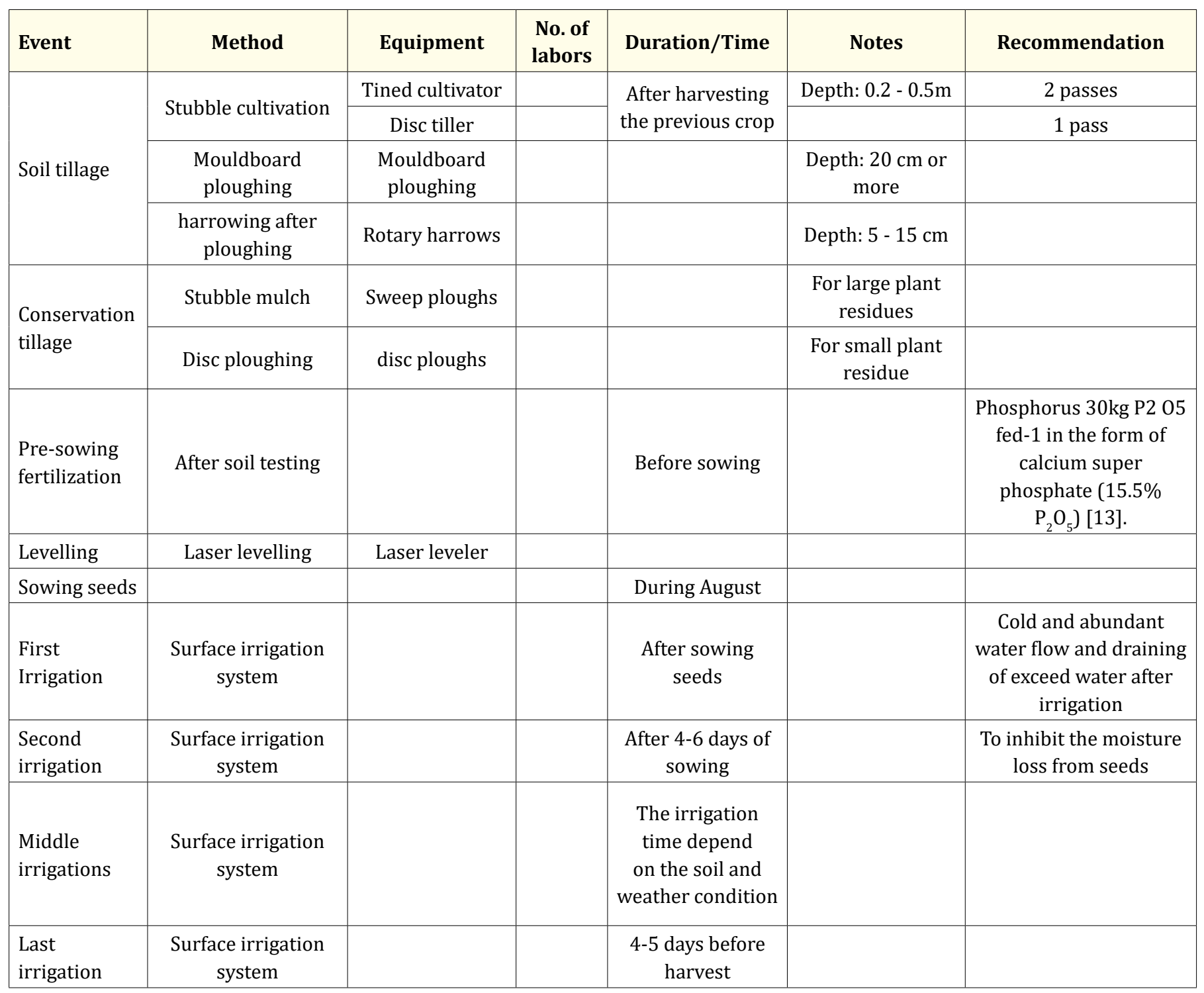




\begin{tabular}{|c|c|c|c|c|}
\hline $\begin{array}{l}\text { Sprinkler } \\
\text { irrigation }\end{array}$ & \multicolumn{4}{|c|}{$\begin{array}{l}\text { In the case of sprinkler irrigation, especially in sandy and light lands, the need for continued availability of moisture } \\
\text { around the seed until germination is completed, and then irrigation is carried out according to the condition of the } \\
\text { plant and soil. }\end{array}$} \\
\hline \multirow[t]{2}{*}{ Thinning } & Hand thinning & 25/acre & $\begin{array}{l}\text { 4-leafs stage }(30 \\
\text { days after } \\
\text { sowing) }\end{array}$ & \\
\hline & Mechanical thinning & & & \\
\hline \multirow{2}{*}{ Fertilization } & Nitrogen & & $\begin{array}{c}\text { 1st dose after } \\
\text { thinning } \\
\text { 2nd dose after } 30 \\
\text { days of thinning }\end{array}$ & $\begin{array}{l}\text { Nitrogen fertilizer was } \\
\text { added at the } 80 \mathrm{~kg} \mathrm{~N} \\
\text { fed- } 1 \text { in the form of } \\
\text { urea }(46 \% \mathrm{~N}) \text { in two } \\
\text { equal doses [13]. }\end{array}$ \\
\hline & Potassium & & $\begin{array}{l}\text { Before the } 2^{\text {nd }} \\
\text { irrigation }\end{array}$ & $\begin{array}{l}\text { Potassium } 24 \mathrm{~kg} \mathrm{~K}_{2} \mathrm{O} \\
\text { fed-1 in the form of } \\
\text { potassium sulphate } \\
\left(48 \% \mathrm{~K}_{2} \mathrm{O}\right) \text { before the } \\
\text { 2nd irrigation [13]. }\end{array}$ \\
\hline \multirow{11}{*}{ Pest control } & Mole cricket & & Aug - Sep & $\begin{array}{c}\text { Avoid weed condensa- } \\
\text { tion. }\end{array}$ \\
\hline & Cutworm & & Late Oct - Nov & \\
\hline & $\begin{array}{l}\text { Egyptian cotton leaf } \\
\text { worm }\end{array}$ & & Aug - Sep & \\
\hline & Flea beetle & & Dec - Feb & $\begin{array}{c}\text { Avoid weed } \\
\text { condensation. }\end{array}$ \\
\hline & Mangold fly & & Mar - May & \\
\hline & $\begin{array}{l}\text { Cercospora leaf spot } \\
\text { (fungal disease) }\end{array}$ & & Aug & \\
\hline & $\begin{array}{l}\text { Powdery mildew } \\
\text { (fungal disease) }\end{array}$ & & Mar - May & \\
\hline & $\begin{array}{c}\text { Damping off (fungal } \\
\text { disease) }\end{array}$ & & & $\begin{array}{c}\text { Irrigation manage- } \\
\text { ment especially in first } \\
\text { and second irrigation } \\
\text { process }\end{array}$ \\
\hline & Nematodes & & & $\begin{array}{l}\text { Sugar beet have to be } \\
\text { the } 4 \text { th crop rotation } \\
\text { Avoid cultivation } \\
\text { peanut and sunflower. }\end{array}$ \\
\hline & Hollow Heart & & $\begin{array}{l}\text { High moisture } \\
\text { and nitrogen } \\
\text { content }\end{array}$ & $\begin{array}{l}\text { Spacing and nitrogen } \\
\text { fertilizer control. }\end{array}$ \\
\hline & Black heart & & $\begin{array}{l}\text { deficiency of } \\
\text { boron }\end{array}$ & $\begin{array}{l}\text { Irrigation, drainage, } \\
\text { boron \& nitrogen } \\
\text { fertilizers control. }\end{array}$ \\
\hline Weed control & $\begin{array}{l}\text { Hand weeding with } \\
\text { application of } \\
\text { herbicides }\end{array}$ & & $\begin{array}{l}\text { After sowing or } \\
\text { after } 2 \text { true- leaf } \\
\text { stage it depends } \\
\text { on the kind of } \\
\text { weed }\end{array}$ & $\begin{array}{c}\text { Visual observation and } \\
\text { hand weeding }\end{array}$ \\
\hline
\end{tabular}




\begin{tabular}{|c|c|c|c|}
\hline \multirow{3}{*}{ Harvest } & Hand harvesting & \multirow{2}{*}{$\begin{array}{l}\text { The yellowish of } \\
\text { the leaves and } \\
\text { root protrusion } \\
\text { from soil } \\
\text { (180 - } 210 \text { days) }\end{array}$} & \\
\hline & $\begin{array}{l}\text { Mechanical } \\
\text { harvesting }\end{array}$ & & \\
\hline & Storing & & $\begin{array}{c}\text { Normal storage } \\
\text { duration from } 24 \text { to } 48 \\
\text { hours maximum. }\end{array}$ \\
\hline Post-harvest & Saving soil loss & & $\begin{array}{l}\text { Avoid harvesting in wet } \\
\text { conditions. }\end{array}$ \\
\hline
\end{tabular}

Table 6

*Stubble cultivation before mouldboard ploughing should usually only be made in fields with a large number of perennial weeds or for the establishment of an autumn-sown catch crop; otherwise, the negative effects may dominate.

\section{Soil tillage}

- Primary tillage performed when soil moisture is optimum.

- $\quad$ Plowing depth for sugar beet varies depending on soil's clay content. Heavy soils require a depth of up to $0.5 \mathrm{~m}$, whereas sandy soils require usually $0.2-0.4 \mathrm{~m}[14]$.

- Repeatedly growing sugar beet on the same field causes a rapid yield drop, mainly due to increased disease inoculants. Consequently, this practice must be carefully avoided.

\section{Pre-sowing fertilization}

- Includes the necessary elements for the incoming crop, taking into account future losses through water movement, etc. Due to their limited mobility in the soil, when phosphorus, potassium and magnesium fertilization is required, they are normally applied before plowing in autumn in order to loosen the fertilizers in the processed soil layer [15].

- It is important not to give too few or too many plant nutrients, therefore the soil must first be analyzed so that the plants will not be burned, or show poor growth.

\section{Sowing}

- To reach to desired concentration of sugar we have to take in our consideration the density of the plant to plant approximately 40000 plants/acre.

- The space between each plant $20 \mathrm{~cm}$.

\section{Soil type}

- Sugar beet can grow in a wide variety of soil in Egypt (saline, alkaline and calcareous soils) so it needs to monitor what the exact type that we treat with by soil analysis [13].

\section{Planting period}

- Sugar beet cultivated in Egypt from August to September and it last for 4- 6 months.

Comparison between traditional, precision and advanced agriculture techniques in cultivating sugar beet

\begin{tabular}{|c|c|c|c|}
\hline & Traditional Agriculture & Precision Agriculture & Advanced precision Agriculture \\
\hline Zoning & $\begin{array}{l}\text { Drilling machine used in } \\
\text { sowing seed to avoid the weeds } \\
\text { or any other plant residues [16] } \\
\text { and can used manually by cone } \\
\text { planter [17]. } \\
\text { The seed sowing according to } \\
\text { previous recommendation for } \\
\text { depth and spacing. }\end{array}$ & $\begin{array}{l}\text { Identification of suitable and } \\
\text { unsuitable conditions for } \\
\text { sugar beet based on } \\
\text { meteorological data history } \\
\text { [18]. }\end{array}$ & $\begin{array}{l}\text { A precision study the meteorological history of } \\
\text { the desired location and except the productivity } \\
\text { of the crop using GIS map and gathered } \\
\text { information about the crop critical growth points. } \\
\text { Management Zone Delineation (MZD) there is are } \\
\text { a various approach in precision } \\
\text { agriculture it's important to collect a real time } \\
\text { data like;(weather, soil, air quality, crop maturity) } \\
\text { [19]. } \\
\text { Zone dividing to be under more control and for } \\
\text { easily data collection. }\end{array}$ \\
\hline Soil analysis & $\begin{array}{l}\text { Based on some recommendation } \\
\text { from another farmers }\end{array}$ & $\begin{array}{c}\text { Soil analysis before planting } \\
\text { that lead to complete image } \\
\text { about the soil and its mineral } \\
\text { losses. } \\
\text { Also soil texture mapping } \\
\text { that provided by satellite } \\
{[20,21] \text {. }}\end{array}$ & $\begin{array}{l}\text { After soil analysis and optimizing all plant needs, } \\
\text { schedule soil analysis period and finally follow } \\
\text { the crop with soil sensors that applied for } \\
\text { different parameters (PH, Moisture, temperature, } \\
\text { Insects, Weeds, pollutants) using NIR [22]. }\end{array}$ \\
\hline
\end{tabular}




\begin{tabular}{|c|c|c|c|}
\hline $\begin{array}{l}\text { Monitoring of } \\
\text { plant } \\
\text { phenotype }\end{array}$ & $\begin{array}{l}\text { The determination of the leaf } \\
\text { area index of sugar beet } \\
\text { canopies by using direct } \\
\text { measurement techniques is very } \\
\text { laborious [23]. } \\
\text { The fresh weight of root is a } \\
\text { destructive test that cannot be } \\
\text { performed before harvest. }\end{array}$ & $\begin{array}{c}3 \text { growth indicator FWL, FWT } \\
\text { and LAI (Fresh weight of } \\
\text { leaves - Fresh Weight of } \\
\text { Roots - leaf Area Index) [24]. }\end{array}$ & $\begin{array}{l}\text { Real-time multispectral camera that based on } \\
\text { unmanned aerial systems that follow the plant } \\
\text { growth. } \\
\text { Knowledge aware system that collects data from } \\
\text { multispectral analysis and cameras and } \\
\text { environmental sensors to reproduce a complete } \\
\text { plant 3D module. }\end{array}$ \\
\hline $\begin{array}{l}\text { Diseases } \\
\text { management }\end{array}$ & $\begin{array}{l}3 \text { different applications of dis- } \\
\text { eases management: } \\
1-\quad \text { Preventive } \\
\text { management } \\
\text { 2- } \\
\text { 3- } \\
\text { Curative management } \\
\text { management }\end{array}$ & $\begin{array}{l}\text { Study the crop pathogens } \\
\text { and apply of the pesticides to } \\
\text { avoid any infection. } \\
\text { The visual plant disease } \\
\text { estimation by human } \\
\text { raters, microscopic } \\
\text { evaluation of morphology } \\
\text { features to identify } \\
\text { pathogens, as well as } \\
\text { molecular, serological, and } \\
\text { microbiological diagnostic } \\
\text { techniques [25]. } \\
\text { It is able to detect Cercospora } \\
\text { leaf spot, powdery mildew, } \\
\text { and rust on sugar beet before } \\
\text { the appearance of visible } \\
\text { symptoms using Support } \\
\text { Vector Machines and spectral } \\
\text { vegetation indices [26]. }\end{array}$ & 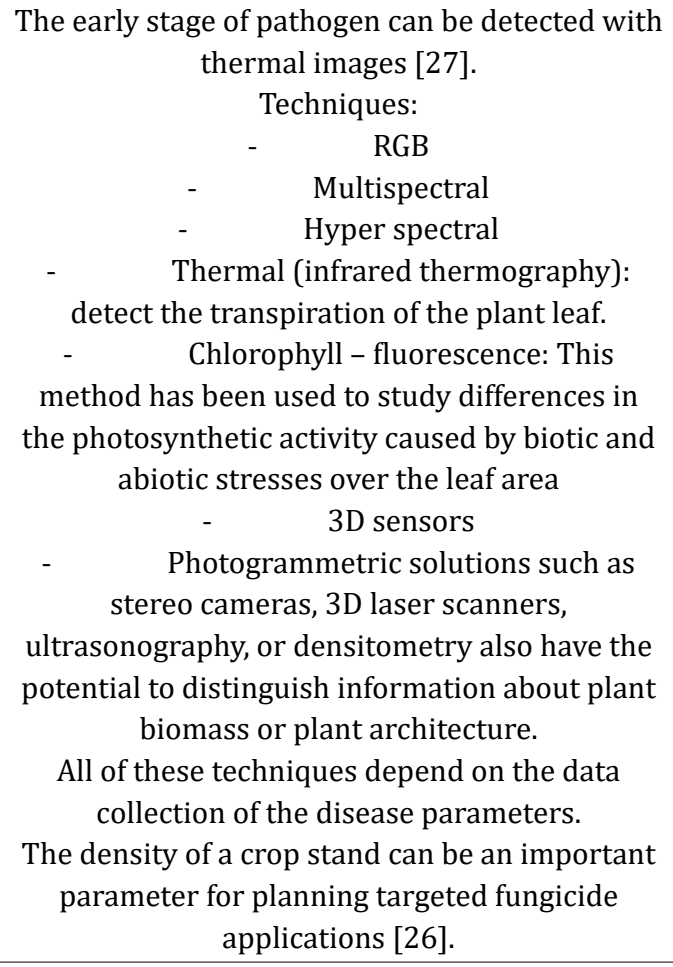 \\
\hline $\begin{array}{l}\text { Water } \\
\text { management }\end{array}$ & $\begin{array}{l}\text { Recommended crop sequences } \\
\text { and change irrigation method } \\
\text { from furrow irrigation to } \\
\text { sprinkler. } \\
\text { Visual observation of soil } \\
\text { moisture. }\end{array}$ & $\begin{array}{l}\text { Most growers who have used } \\
\text { watermark moisture soil } \\
\text { sensors reduced their water } \\
\text { use and observed slight } \\
\text { increases in yield. }\end{array}$ & $\begin{array}{l}\text { High-resolution multi-spectral imagery, in } \\
\text { combination with ground sampling, provided } \\
\text { enough information for the modelling } \\
\text { approaches to accurately estimate spatially } \\
\text { distributed surface soil moisture [28]. } \\
\text { Real-time canopy temperature, relative humidity, } \\
\text { solar radiation, wind speed and air temperature } \\
\text { were required field measurements for calculating } \\
\text { theoretical CWSI (Crop Water Stress index) for } \\
\text { automatic irrigation [29]. }\end{array}$ \\
\hline Fertilization & $\begin{array}{l}\text { Application of recommended } \\
\text { brand name of fertilizers that } \\
\text { contain NPK. }\end{array}$ & $\begin{array}{l}\text { Variable rate fertilization is } \\
\text { applied according to the zone } \\
\text { mapping of mineral defection } \\
\text { that need to be fertilized. }\end{array}$ & $\begin{array}{l}\text { Perform soil and water analysis and during } \\
\text { application following the plant by NDVI values } \\
{[30] .} \\
\text { Site specific fertilization: } \\
\text { Fertilizing Based on Nutrient Removal } \\
\text { by Previous Crops. } \\
\text { Real time fertilization: } \\
\text { 1- } \quad \text { Fertilizing Based on Reflectance of Soils } \\
\text { [31]. }\end{array}$ \\
\hline Seeding & $\begin{array}{l}\text { Manual sowing of seed without } \\
\text { takes any consideration to soil } \\
\text { sampling or any other } \\
\text { recommendation. }\end{array}$ & $\begin{array}{l}\text { Detection the soil moisture } \\
\text { from soil sampling and take } \\
\text { the recommended spaces } \\
\text { between each seed and raw } \\
\text { and depth. }\end{array}$ & $\begin{array}{c}\text { Sensor used in during seeding for detect } 2 \\
\text { important point sowing depth and soil moisture } \\
\text { [31]. }\end{array}$ \\
\hline
\end{tabular}

Table 7

* Automatic irrigation triggered only after canopy temperatures exceeded $28^{\circ} \mathrm{C}$ for more than 452 min accumulated in a $24 \mathrm{~h}$ period on an odd-numbered DOY in cotton [32]. 


\section{Recommendation}

- Zoning land according to GIS (Geographical Information System) and dividing zoning area to blocks for precision agriculture.

- Precision reference study of the cultivar for its resistance and productivity.

- $\quad$ Soil testing before cultivation (A 60 -acre field with 3 sampling areas would require 15-20 cores for each of 3 composite boxed or bagged samples).

- $\quad$ Real- time water and soil measurement (parameters) daily updated schedule.

- Automatic valves to control irrigation schedule.

- Monitoring of canopy temperature and soil surface temperature for early pathogen detection.

- The WSN (Wireless sensor network) can be used to test the suitability of the agricultural land to the crop cultivation, ensuring its freeness from diseases and harmful fungi, and for performing nutrient availability analysis in order to develop an appropriate fertilization scheme.

\section{Important notes}

- Crop sequence in land for high productivity Clover (short season), sugar beet then rice.

- $\quad$ Sugar beet, soybean then maize for water management and soil mineral saving.

- Faba bean can intercrop with sugar beet.

- When the crop is imported to the factory, a sample is taken and the percentage of sucrose, sodium, potassium, and alpha-amino nitrogen is estimated. The higher the percentage of the last three elements, the lower the percentage of sugar extraction.

- $\quad$ Soil physical analyses

- Particle size distribution, bulk density, and soil compaction by soil core method were determined according to [33].

\section{Soil chemical analyses}

Electric conductivity (EC), soluble cations and anions, calcium carbonate $\left(\mathrm{CaCO}_{3}\right)$, organic matter, $\mathrm{pH}$, exchangeable $\mathrm{Na}+$, macronutrients, and cation exchange capacity were determined according to United States Department of Agriculture [34].

\section{Water samples analyses}

- Three water sampling tests (pH, EC, total dissolved solids (TDS), and sodium adsorption ratio (SAR)) were carried out using the soil survey laboratory methods manual [34].

- Suitability of water for irrigation was determined according to the limitations outlined by [35].

\section{Late harvesting impact}

The late harvest (187 after emergence) obtaining the highest sugar yield when the rainfall and low temperature do not occur [36].

\section{Bibliography}

1. Zeinab E Ghareeb., et al. "Genotype $\times$ environment interaction for characteristics of some sugar beet genotypes" (2014).

2. Carlyle DH. "A Growing Degree Day Equation for Predicting Early Sugarbeet Leaf Stages". Ph.D. Dissertation, Plant Sciences Dept., North Dakota State University, Fargo, USA (1998).

3. Khalifa E and Meleha M. "Sugar beet production under drip irrigation in heavy clay soil". Journal of Soil Sciences and Agricultural Engineering 34 (2009): 7467-7480.

4. Zaki, Safi-Naz. "Influences of Irrigation and Fertilizer on Growth and Yield of Two Sugar Beet Varieties in Egypt" (2017).

5. HI El-Eila., et al. "Nutrient response of three sugar beet varieties grown under new reclaimed soils to potassium and boron fertilization". International Journal of Academic Research 6 (2014): $269-273$.

6. Hanan Y Mohamed and MAT Yasin. "Response of Some Sugar Beet Varieties to Harvesting Dates and Foliar Application of Boron and Zinc in Sandy Soils". Egyptian Journal of Agronomy 35.2 (2013): 227-252.

7. Aly E., et al. "Effect of hill spacing and cease irrigation before harvesting on som sugar beet varities under sandy soils". Journal of Plant Production 3 (2012): 1039-1047.

8. Abbas Mohamed., et al. "Effect of some soil amendments on yield and quality traits of sugar beet (Beta vulgaris L.) under water stress in sandy soil". Egyptian Journal of Agronomy 40.1 (2018).

9. Kamal K Attia., et al. "Response of Sugar Beet Grown in Newly Reclaimed Soil to Different Nitrogen Sources at Different Growth Stages". Middle East Journal of Agriculture Research (2015). 
10. van Burg PFJ., et al. "Nitrogen supply from fertilizers and manure: Its effect on yield and quality of sugar beet. In Nitrogen and sugar-beet, 189-292". Brussels, Belgium: IIRB (1983).

11. Abdel-Motagally FMF and KK Attia. "Response of sugar beet plants to nitrogen and potassium fertilization in sandy calcareous soil". International Journal of Agriculture and Biology 11 (2009): 695-700.

12. Hassanli AM., et al. "Evaluation of the influence of irrigation methods and water quality on sugar beet yield and water use efficiency". Agricultural Water Management 97.2 (2010): 357362.

13. Mirvat E Gobarah., et al. "Effect of Different Sowing Dates on Quantity and Quality of Some Promising Sugar Beet (Beta vulgaris L.) Varieties under North Delta, Condition". Egyptian Journal of Agronomy 41.3 (2019): 343-354.

14. Koch HJ., et al. "Yield decrease in sugar beet caused by reduced tillage and direct drilling". European Journal of Agronomy 30 (2009): 102-109.

15. Martindale W. "The sustainability of the sugar beet crop-the potential of add value". British Sugar Beet Review 81 (2013): 49-52.

16. Stevanato Piergiorgio., et al. "Sustainability of the Sugar Beet Crop". Sugar Tech (2019): 21.

17. Kaffka Stephen and Hembree Kurt. "The Effects of Saline Soil, Irrigation, and Seed Treatments on Sugarbeet Stand Establishment". Journal of Sugarbeet Research 41 (2004): 61-72.

18. Stol W., et al. "Agro-ecological characterization for potato production". CABO-DLO Report 155, Wageningen, the Netherlands 53 (1991).

19. Janrao Prachi. "Management Zone Delineation in Precision Agriculture Using Data Mining: A Review" (2015).

20. Wang DC., et al. "Mapping soil texture of a plain area using fuzzy-c-means clustering method based on land surface diurnal temperature difference". Pedosphere 22 (2012): 394-403.

21. Wang DC., et al. "Retrieval and mapping of soil texture based on land surface diurnal temperature range data from MODIS". PLoS ONE 10 (2015): e0129977.

22. Yin H., et al. "Soil Sensors and Plant Wearables for Smart and Precision Agriculture". Advanced Materials 33 (2021): 2007764.
23. Röver A and Koch H J. "Indirect determination of leaf area index of sugar beet canopies in comparison to direct measurement". Journal of Agronomy and Crop Science 174 (1995): 189195.

24. Yang Cao., et al. "Monitoring of sugar beet growth indicators using wide-dynamic-range vegetation index (WDRVI) derived from UAV multispectral images". Computers and Electronics in Agriculture 171 (2020): 105331.

25. Mahlein Anne-Katrin. "Plant Disease Detection by Imaging Sensors - Parallels and Specific Demands for Precision Agriculture and Plant Phenotyping". Plant Diseases 100.2 (2016): 241-251.

26. Rumpf T., et al. "Early detection and classification of plant diseases with support vector machines based on hyperspectral reflectance". Computers and Electronics in Agriculture 74 (2010): 91-99.

27. Mahlein AK., et al. "Recent advances in sensing plant diseases for precision crop protection". European Journal of Plant Pathology 133 (2012): 197-209.

28. Hassan-Esfahani Leila., et al. "Assessment of Surface Soil Moisture Using High-Resolution Multi-Spectral Imagery and Artificial Neural Networks". Remote Sensing 7.3 (2015): 2627-2646.

29. Osroosh Y., et al. "Automatic irrigation scheduling of apple trees using theoretical crop water stress index with an innovative dynamic threshold". Computers and Electronics in Agriculture 118 (2015): 193-203.

30. Ursoy Onder and Atun Rutkay. "Using Remote Sensing in Detecting Sugar Beet Fields Treated with Different Doses of Phosphorus". Fresenius Environmental Bulletin 28 (2019): 1247-1253.

31. HJ Heege. "Precision in Crop Farming: Site Specific Concepts and Sensing 143 Methods: Applications and Results” (2013).

32. O'Shaughnessy SA and Evett SR. "Canopy temperature based system effectively schedules and controls center pivot irrigation of cotton". Agricultural Water Management 97 (2010): 1310-1316.

33. Klute A. "Methods of soil analysis (part 1)-physical and mineralogical methods". American Society of Agronomy and Soil Science Society of America, Madison (1986).

34. USDA. Soil Survey Laboratory Methods Manual. Soil Survey Investigation Report No. 42 Version 4.0 November 2004 (2004). 
35. FAO. "Land evaluation for irrigated agriculture". Soils bulletin 55. FAO, Rome (1985).

36. Heidari G., et al. "Influence of harvesting time on yield and yield components of sugar beet". Journal of Agriculture, Forestry and the Social Sciences 4.2 (2008): 69-73.

\section{Assets from publication with us}

- Prompt Acknowledgement after receiving the article

- Thorough Double blinded peer review

- Rapid Publication

- Issue of Publication Certificate

- High visibility of your Published work

Website: www.actascientific.com/

Submit Article: www.actascientific.com/submission.php

Email us: editor@actascientific.com

Contact us: +919182824667 